\title{
Telomerase and telomeres in aging theory and chronographic aging theory (Review)
}

\author{
MAYYA P. RAZGONOVA ${ }^{1,2}$, ALEXANDER M. ZAKHARENKO ${ }^{1,2}$, \\ KIRILL S. GOLOKHVAST ${ }^{1-3}$, MARIA THANASOULA ${ }^{4}$, EVANGELIA SARANDI ${ }^{4}$, \\ KONSTANTINOS NIKOLOUZAKIS ${ }^{5}$, PERSEFONI FRAGKIADAKI ${ }^{5,6}$, DIMITRIS TSOUKALAS ${ }^{4}$, \\ DEMETRIOS A. SPANDIDOS ${ }^{7}$ and ARISTIDIS TSATSAKIS ${ }^{5,6}$
}

\author{
${ }^{1}$ N.I. Vavilov All-Russian Institute of Plant Genetic Resources, 190000 Saint-Petersburg; \\ ${ }^{2}$ Far Eastern Federal University, 690950 Vladivostok; ${ }^{3}$ Pacific Geographical Institute, \\ Far Eastern Branch of The Russian Academy of Sciences, 690041 Vladivostok, Russia; \\ ${ }^{4}$ Metabolomic Medicine, Health Clinics for Autoimmune and Chronic Diseases, 10674 Athens; \\ ${ }^{5}$ Laboratory of Toxicology, Medical School, University of Crete, 71003 Heraklion; ${ }^{6}$ Spin-Off Toxplus S.A., \\ 71601 Heraklion; ${ }^{7}$ Laboratory of Clinical Virology, School of Medicine, University of Crete, Heraklion 71003, Greece
}

Received April 17, 2020; Accepted June 24, 2020

DOI: $10.3892 / \mathrm{mmr} .2020 .11274$

\begin{abstract}
The current review focuses on the connection of telomerase and telomeres with aging. In this review, we describe the changes in telomerase and telomere length (TEL) during development, their role in carcinogenesis processes, and the consequences of reduced telomerase activity. More specifically, the connection of TEL in peripheral blood cells with the development of aging-associated diseases is discussed. The review provides systematic data on the role of telomerase in mitochondria, the biology of telomeres in stem
\end{abstract}

Correspondence to: Professor Aristidis Tsatsakis, Laboratory of Toxicology, Medical School, University of Crete, P.O. Box 1393, 71003 Heraklion, Greece

E-mail: tsatsaka@uoc.gr

Abbreviations: hTERT, human telomerase reverse transcriptase; TRF1, telomeric repeat binding factor 1; TRF2, telomeric repeat binding factor 2; PB, peripheral blood; HPMCs, human peritoneal mesothelial cells; ALT, alternative lengthening of telomeres; Q-FISH, quantitative fluorescence in situ hybridization; SDH, succinate dehydrogenase; $\mathrm{FH}$, fumarate hydratase; IDH1, isocitrate dehydrogenase 1; lncRNAs, long non-coding RNA; tRNA, transfer RNA; rRNA, ribosomal RNA; mRNA, messenger RNA; TERC, telomerase RNA component; PNPase, polynucleotide phosphorylase; PDL, population doublings; TEL, telomere length; PBLs, peripheral blood leukocytes; Flow-FISH, fluorescence in situ hybridisation and flow cytometry; WB, whole blood; HSC, hematopoietic stem cells; MSC, mesenchymal stem cells; ATP, adenosine triphosphate; NPC, Niemann-Pick C disease; SMCs, smooth muscle cells; LDL, low-density lipoprotein cholesterol; ROS, reactive oxygen species

Key words: chronomere, stem cells, telomerase, telomere, theory of aging cells, as well as the consequences of the forced expression of telomerase (telomerization) in human cells. Additionally, it presents the effects of chronic stress exposure on telomerase activity, the effect of TEL on fertility, and the effect of nutraceutical supplements on TEL. Finally, a comparative review of the chronographic theory of aging, presented by Olovnikov is provided based on currently available scientific research on telomere, telomerase activity, and the nature of aging by multicellular organisms.

\section{Contents}

1. Introduction

2. Telomeres and telomerase: The generation of aging theory

3. Telomerase activity and aging

4. Chronographic theory of aging: Neural chronograph

5. Conclusions and future research directions

\section{Introduction}

Genetic information is stored in linear DNA molecules - chromosomes in eukaryotic cells (1). McClintock and Möller in 1930 found that complete chromosomes and their fragments behave differently in the cells $(2,3)$. The different properties of chromosomes could be due to the presence of special nucleotide sequences at the chromosomal ends, which are called telomeres (4). Telomeres consist of repeating nucleotide sequences and a set of special proteins that interact with DNA to form a nucleoprotein complex (5). When these repetitive sequences were used for in situ hybridization, the following conclusions were made: Human heterochromatin is composed of some heterochromatic pieces, (e.g., that of chromosome) that appear to have more heterogeneous composition than others, while the highly repetitive human DNA fractions are located 
primarily at the centromeric and telomeric regions. Moreover, more slowly re-associating repetitious sequences are distributed along the chromatid, with a slight bias towards telomeric regions (6). During each cell division, the 5' end of the newly synthesized strand shortens due to the deletion of terminal RNA primer, leading to incomplete replication of linear DNA molecules. Olovnikov (1971) and Watson (1972) independently formulated the 'problem of insufficient replication' in the 1970s $(7,8)$.

Aging is caused by degenerative diseases, which generates an irreversible accumulation of mutations, inability of cell division, increased susceptibility to morbidity, and ultimately death. Human cells can undergo a limited number of cell divisions and eventually reach an indivisible state called replicative senescence, as telomeres get shorter in each cell division. The link between aging and cancer is a critical aspect of modern research. Unlimited replicative potential, or immortality, is considered the main factor distinguishing cancer cells from normal cells. Numerous studies have shown that tumour cell immortality is associated with the activation of the enzyme telomerase that is responsible for telomere replication and compensates for the telomere shortening that occurs during each cell division. Since the development of methods able to determine telomerase activity, many human tissue samples have been examined for the presence of telomerase activity. Telomerase activity has been recorded in more than $85 \%$ of malignant tumours, whereas it was absent in normal tissue cells (9). It is claimed that telomere shortening may be the molecular clock that triggers aging. Studies attempted to verify this hypothesis, by transfecting two telomerase-negative normal human cell types, retinal epithelial cells and foreskin fibroblasts, with vectors encoding the catalytic subunit of human telomerase (hTERT). Unlike the control clones that were telomerase-negative and exhibited telomere shortening and aging, telomerase-positive clones had elongated telomeres and exhibited reduced staining for $\beta$-galactosidase, which is an aging biomarker. Importantly, telomerase-positive clones exceeded their normal life expectancy by at least 20 doublings, making it possible to establish a link between telomere shortening and cellular aging in vitro $(10,11)$. Moreover, apart from the inhibition of telomerase activity, telomere shortening may be a result of loss of telomere protection and stability. This is caused by the accumulation of unrepaired DNA damage during the cell cycle via destabilization of telomeric protein complexes such as Shelterin complex components i.e. telomeric repeat binding factor 1 and 2 (TRF1 and TRF2) (Fig. 1) (12-15).

\section{Telomeres and telomerase: The generation of aging theory}

In a historical perspective, Hayflick and Olovnikov greatly contributed to the field of telomeres and telomerase, with the work of Hayflick in 1961, triggering many scientists to try to explain how cells count their divisions (16). He showed that human cells divide only a limited number of times in culture, while at that time the public opinion was dominated by the conviction that $\mathrm{T}$ cells are immortal in the hands of a skilled researcher. The article received a tremendous public response and the term 'Hayflick limit' was created and included in the dictionaries.
At first, the telomere functions were unknown, and the sequence of their nucleotides was not known either. In 1958, the DNA polymerase enzyme responsible for DNA replication was discovered by Lehman et al (17) and Bessman et al (18). DNA polymerase binds to a primer, a short RNA fragment sitting on a DNA strand, that is synthesized by another enzyme in order to initiate replication of telomeres and is subsequently removed. During replication, DNA polymerase moves from the 5'-end to the 3'-end, and as a result, it cannot replicate the entire DNA molecule (there should be a non-copied fragment on one of the ends to which it is attached), the so-called end replication problem. Olovnikov (1971) and Watson (1972) first noticed this in their independent observations $(7,8)$. Later, Olovnikov (1973) published the 'theory of marginotomy' that can be considered a response to the work of Hayflick (1961), explaining how the division counter works (19). In this work it was predicted that in the case of the matrix synthesis of a linear polynucleotide (chromosome replication), the copy should be shorter leading to the limitation of the number of cell divisions observed. Also, the existence of a special enzyme that extends the ends of chromosomes in immortal cells was discussed.

The studies of Greider and Blackburn led the discovery of telomerase in 1984, suggesting that the sequences at the ends of chromosomes may have some special replication mechanism (20). Moreover, Szostak and Blackburn studied the molecular mechanisms of the theory of Möller and McClintock, according to which, telomeres are required for chromosome stabilization (2,3). Importantly in 1988, Harley combined the idea of Olovnikov with the studies of Greider and Blackburn, leading to a breakthrough in the field (21) i.e., observing a shortening of telomeres in human cells overtime (22).

\section{Telomerase activity and aging}

Telomerase is an enzyme responsible for the replication of the telomeric regions of chromosomal DNA. It is known that shortening of telomeric regions of DNA to critically short length can serve as a signal for the replicative senescence of somatic cells and destabilization of their chromosomes (23). Telomerase activity combined with the telomere length (TEL) reflects the cell's proliferative potential (24). Telomerase activity is mainly present in stem, sex, and tumor cells but there is also evidence of detectable activity in intestinal mucous cells, in lymphocytes of peripheral blood (PB), and thymus (25). In addition, the catalytic subunit of telomerase (hTERT), which is an RNA-dependent DNA polymerase that synthesizes telomeric repeats, as well as the mRNA of this subunit, is also expressed in these cells at a relatively low, but detectable level.

During life, telomeres of PB lymphocytes gradually shorten due to cell division, accumulating with age in vivo (25). It has been shown that in many diseases, including immune-associated diseases (rheumatoid arthritis, atopic dermatitis, and bronchial asthma), PB lymphocytes are characterized by shortened telomeres and increased proliferation compared with those in healthy lymphocytes. Numerous studies have shown that telomere shortening may contribute to osteoarthritis and osteoporosis as an epigenetic factor and it is further supported 


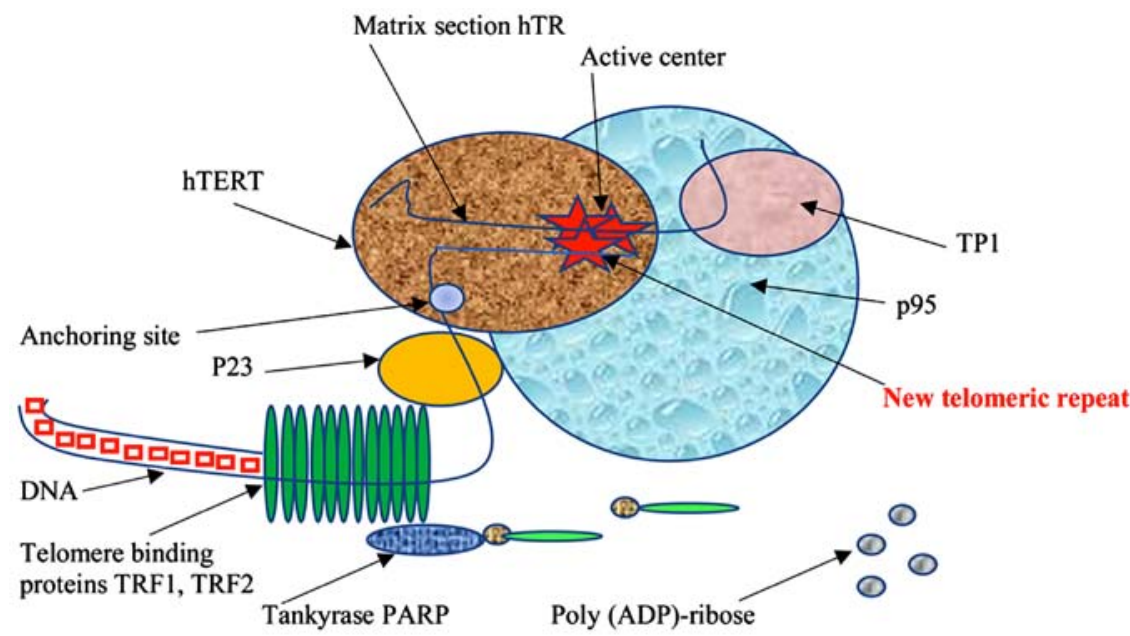

Figure 1. Schematic representation of the interaction of the telomeric complex (comprised of TRF1, TRF2) with a part of telomeric DNA. Protein components include p95, p23 and TP1 proteins, as well as the catalytic subunit hTERT, which performs the synthesis of telomeric repeats. Moreover, tankyrase PARP is depicted to also interact with the telomeric complex. TRF, telomeric repeat binding factor; hTERT, human telomerase reverse transcriptase; PARP, poly (ADP)-ribose polymerase.

that TEL measurement of chondrocytes and PB cells may be an appropriate marker for the evaluation of the progression of these diseases (26-29). Moreover, other factors can influence the rate of telomere shortening in lymphocytes, such as the presence of chronic stress (30) and drug abuse (31). It has been shown that telomerase expression in lymphocytes is strictly controlled during their development, differentiation, and activation (30), and because of stimulation, 'adult' lymphocytes become capable of expressing telomerase at a rather high level. After any re-stimulation, telomerase expression may also increase but its level does not reach the level of response to the primary stimulus (32). Such dynamics may reflect the regulatory mechanisms of clonal expansion of lymphocytes, which is part of the immune response and control mechanism of their proliferation.

Somatic cells are mostly devoid of telomerase activity. It is suggested that telomerase activity can be regulated in human cells by intranuclear transfer of key components. It was shown in HeLa cervical carcinoma cells that hTR and hTERT, during most of the cell cycle, accumulate in intranuclear sites separately from telomeres, whereas during $\mathrm{S}$ phase, they are specifically recruited at telomeres. Therefore, the recruitment of telomerase at telomeres is dynamic, reaching a peak in the middle of S phase. Moreover, both hTR and hTERT are associated with nucleoli and Cajal bodies during $\mathrm{S}$ phase, participating in telomerase transfer (33). Interestingly, human peritoneal mesothelial cells (HPMCs) appear to have unusually short telomeres $(3.5 \mathrm{kbps})$ despite the presence of active telomerase. These telomeres do not shorten due to aging but due to a decrease in telomerase activity. HPMC aging is associated with mitochondrial dysfunction, leading to increased production of active oxygen species and reduced mitochondrial membrane potential, indicating that premature aging is highly associated with oxidative damage in non-telomeric regions of the genome (34).

Telomerase activity in autoimmune diseases, such as rheumatoid arthritis, lupus erythematosus, atypical dermatitis, psoriasis, multiple sclerosis, and aplastic anaemia is summarized and presented in Table I.
ALT-alternative lengthening of telomeres. In addition to telomerase activation, there is a telomere lengthening mechanism, alternative to telomerase (ALT-alternative lengthening of telomeres). However, this mechanism in mammalian cells is only present in abnormal situations, such as in cancer cells, immortalized cell lines, and murine cell knockout for the telomerase gene, whereas normal human lymphocytes cannot use ALT to maintain their telomeres. A minority of immortal cell lines and tumor cells use ALT to counteract telomere erosion due to cell division $(35,36)$. Observations on the dynamics of the TEL of immortalized cells suggest that this mechanism is based on recombination, resulting in individual telomeres that undergo rapid shortening and rapid elongation (37). Besides, ALT cells can lengthen their telomeres using telomeric sequences from other chromosomes as a template for new DNA synthesis $(38,39)$. Cesare and Reddel (2010) convincingly proved in their research that tumor cells treated with telomerase inhibitors can activate the ALT pathway for telomeric maintenance through recombination (40). This can explain the therapeutic failures and/or a resistance against telomerase inhibition-based anti-cancer therapy. Therefore, developing new therapeutics targeting proteins known to be involved in the latter pathway will be crucial for the targeting of ALT-specific cells (41).

Telomerase is the main mechanism for stabilizing telomeres in lymphocytes and they use it to reduce telomere shortening during cell proliferation (42). Thus, in intact lymphocytes in systemic lupus erythematosus, multiple sclerosis, and atopic dermatitis, telomerase activity is enhanced (43). Moreover, quantitative fluorescence in situ hybridization (Q-FISH) on metaphase chromosomes in the PB lymphocytes showed that the distribution of TEL for individual chromosomes differs in normal and pathological conditions. Patients with rheumatoid arthritis had significantly shorter telomeres of chromosome $4 \mathrm{p}$, an observation that could be related to the pathology of the disease, while the activity of the disease is inversely correlated with the length of the telomeres of the $10 \mathrm{p}$ chromosome which carries the genes involved in the differentiation and proliferation of T-cells (44). The dynamic activity 


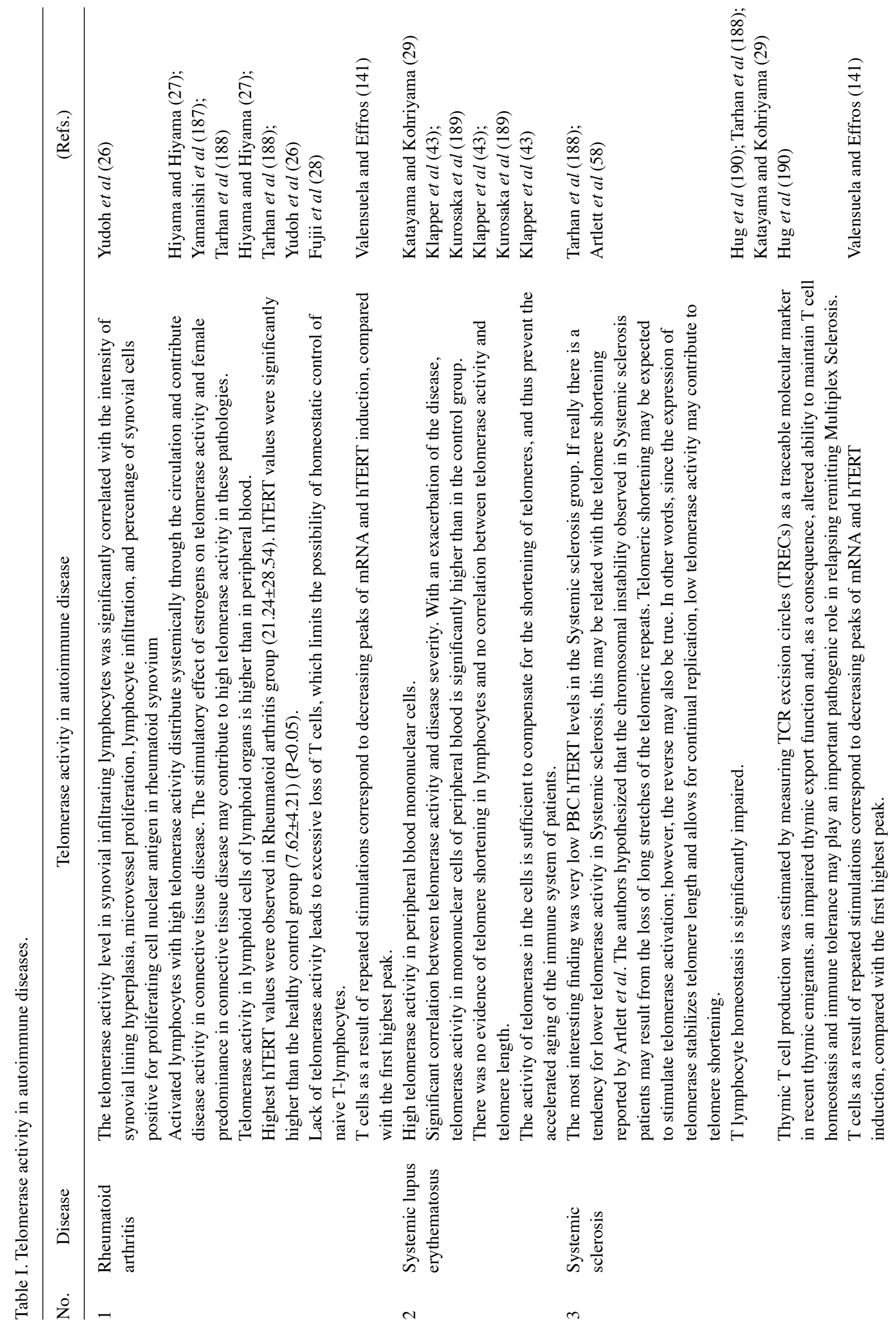


of telomerase is correlated with the action of an acute stressor and with two types of reactions to stress-psychological stress and neuroendocrine (cortisol) responses to the stressor (24). Several studies indicate that in most of the above situations (immunopathological diseases, stress, and many others) the telomeres of lymphocytes shorten with age faster than in healthy individuals $(45,46)$.

Role of telomerase in mitochondria. It is known that mitochondrial dysfunctions are found in metabolic disorders, neurodegenerative diseases, and autoimmune diseases $(47,48)$. Mitochondria are important organelles for the production of bioenergy, for biosynthesis and signaling, thus an integral part of cellular adaptation to the environment. Concomitantly, mitochondria are important mediators of carcinogenesis, since this process requires flexibility for the cells to adapt to the environmental changes. Many aspects of mitochondrial biology support transformation, including mitochondrial biogenesis and metabolism, fusion dynamics, regulation of oxidative stress, and cell-signaling. Thus, understanding the mechanisms of mitochondrial function during cancer genesis is critical for future cancer treatment (49). Mutations in mitochondrial genes are common in cancer cells, they do not inactivate mitochondrial energy metabolism but rather alter the mitochondrial bioenergetic and biosynthetic state, including succinate dehydrogenase, fumarate hydratase, and isocitrate dehydrogenase 1 , which lead to an increase in the level of succinate, fumarate or R-2-hydroxyglutarate. These metabolic changes can inhibit $\alpha$-ketoglutarate-dependent dioxygenases, possibly contributing to oncogenesis (50).

Disruption of mitochondrial activity is directly related to neurodegenerative diseases, indicative of the importance of mitochondrial functions in normal cellular physiology. Recent studies focused on mitochondrial function in reactive oxygen generation and its participation in the development of neurodegenerative diseases (51).

As is generally known, the mitochondrial genome is a highly replicated, specialized genetic system that allows individual mitochondria to respond to changes in membrane potential and support oxidative phosphorylation by gene expression (52). Studying this special role, one should not be surprised that the mitochondrial genome is regulated and expressed in a unique way. Human mitochondria contain a compact ring genome of 16,569 bp in length (53). Replication and transcription of mitochondrial DNA (mtDNA) is initiated from the non-coding region, loop $\mathrm{D}$, and is regulated by nuclear-encoded proteins that are post-translationally imported into mitochondria. Mitochondrial RNAs are transcribed as long polycistronic precursor transcripts from 'heavy' and 'light' chains, which are processed according to the 'tRNA punctuation model', whereby 22 disseminated tRNAs are excised to release rRNA and mRNA (54). The released RNAs then undergo maturation, which involves the polyadenylation of 30 ends of mRNA and rRNA (55). Together, this includes a unique genetic system that is able to translate genes encoded by mitochondria into 13 protein subunits of the electron transfer chain. The subtle features of the mitochondrial transcriptome are still poorly understood: Regulation of the number of transcripts, RNA processing and modification sites, and the possible presence of non-coding RNAs. The recent advent of deep sequencing 
has provided a global nuclear transcriptome profile, revealing unanticipated transcription complexity, which includes widespread post-transcriptional processing and an abundance of non-coding RNA (56-58). Mercer et al (2011) used a similar approach to study mitochondrial transcriptome (59).

Wang et al (60) (2010) investigated the import functions of some lncRNAs in mitochondria, showing that one of the RNAs, the RNA component of the telomerase (TERC), is processed in mitochondria and then exported out of mitochondria. Partial disruption of mitochondrial function caused the accumulation of mitochondrial-processed RNA, TERC, in the cytosol. These results provide a potential link between mitochondrial function and telomerase activity. The import of RNA into mitochondria is very important for replication, transcription, and translation of the mitochondrial genome. PNPase is an important regulator of the import of nuclear-encoded RNA into the mitochondrial matrix. It has been shown that the decrease in PNPase impairs mitochondrial RNA processing. Moreover, the increase in imports of RNase P, 5S rRNA, and multidrug resistance proteins RNA is directly dependent on the expression of PNPase. These observations led the identification of PNPase-imported RNA interactions, suggesting a new role of PNPase in providing translocation of RNA to mitochondria (60). In addition, Cheng et al (61) (2018) showed that the RNA component of mammalian TERC telomerase is imported into mitochondria, processed into the shorter form of TERC-53, and then exported back to the cytosol. These data collectively reveal the existence of a pathway of mitochondrial RNA transfer and provide a potential mechanism for transferring the functional states of mitochondria to other cellular compartments.

Several recent reports have studied the transport of hTERT to mitochondria, which is most likely controlled by a mitochondrial sequence at the $\mathrm{N}$-terminus of hTERT. It has been shown that the accumulation of endogenous oxidative stress leads to the hTERT nuclear export to the cytosol, reducing the nuclear and total telomerase activity. The addition of antioxidants slows down this process significantly (62). Aging is associated with an increase in the number of intracellular reactive oxygen species (ROS) and a loss of telomerase activity. Haendeler et al (62) (2004) investigated whether an age-related increase in the number of ROS can induce nuclear export of TERT and promote endothelial cell aging. Haendeler et al found that in parallel with increased ROS formation, the TERT nuclear protein is exported from the nucleus to the cytoplasm and Src kinase is activated. Incubation with $\mathrm{N}$-acetylcysteine reduced the formation of intracellular ROS and prevented mitochondrial DNA damage, as well as low doses of atorvastatin that had a similar effect. Therefore, it has been suggested that antioxidants and statins can delay the onset of replicative aging by counteracting the increase in ROS associated with aging of endothelial cells (62-64).

Telomeric stem cell biology. Most human stem cells are characterized by a rather slow proliferation rate, which was estimated for the hematopoietic stem cells (HSCs), as one division in 1-2 years (65). During the intervals between divisions, the cells are in proliferative rest. However, even with such proliferation rates, it is clear that stem cells have a proliferative potential that is bigger than the Hayflick limit.
The regulation of TEL and telomerase activity is a complex and dynamic process that is tightly linked to cell cycle regulation. HSCs demonstrate telomeric shortening during replicative aging despite expression of low levels of telomerase (66). Granulocytes and naive $\mathrm{T}$ cells showed a parallel two-phase decrease in TEL with age, which most likely reflected the accumulated cell divisions in the HSCs that are the common precursors of both types of cells. Memory T cells also first showed a rapid decrease in TEL with age, which continued for several years, resulting in lymphocytes with shorter telomeres that granulocytes in older people. These results indicate a sharp decrease in stem cell turnover in early childhood and confirm that cell divisions in HSCs and T cells lead to telomere shortening $(67,68)$. Telomere shortening is most pronounced during bone marrow resection, as it has been observed that there is an inverse correlation between the number of transplanted mononuclear cells and the degree of telomere shortening. A bone marrow transplant results in a telomere shortening equivalent to a period of 15 years of life (69).

Interestingly, Scheding et al (70) (2003) attempted to assess whether repeated stimulation of the hematopoietic system due to regular blood sampling will negatively affect the TEL of PB leukocytes (PBLs). It is known that the TEL of PBLs can be used to evaluate HSCs turnover. A study using fluorescence in situ hybridisation and flow cytometry (Flow-FISH), showed that when compared with the corresponding non-donor data, no differences were observed. In addition, neither age-adjusted donor data for TEL for granulocytes nor TEL for lymphocytes correlated with either the total number of years or the total number of whole blood (WB) and/or PLT donations. Long-term donation of WB does not affect TEL, as measured by Flow-FISH, which indicates a significant increase in stem cell turnover (70). Moreover, lymphoid cells are capable of very intensive clonal reproduction with antigenic stimulation. Despite the induction of telomerase, their telomeres are more significantly shortened than in granulocytes. Accordingly, memory cells have significantly shorter telomeres than lymphocytes (71).

There are many unresolved issues in telomeric stem cell biology and the various stem cells of an adult organism vary greatly regarding the role of telomeres and telomerase in maintaining proliferation. These stem cells include HSCs and mesenchymal stem cells (MSCs) from human bone marrow, that are extensively studied. hMSCs are a type of adult stem cells from the bone marrow, which can differentiate into bone, cartilage, adipose, and muscle cells (72). hMSCs show a total absence of telomerase activity, in contrast to HSC and other adult stem cells (73). Ectopic telomerase expression is able to expand their limited replicative ability in tissue culture, maintaining their functional characteristics (74), a feature that can be developed for the application of these cells in tissue engineering (75).

Importantly, stem and cancer cells share several characteristics, including factors that regulate self-renewal in both normal HSCs and leukemic cells (76), leading to the hypothesis of 'cancer stem cells' (77). Cancer stem cells resemble normal stem cells in the sense that when they divide, one of the daughter cells differentiates into a certain type of cell, which eventually ceases to divide, while the other retains its stem cell properties, being able to divide constantly. Cancer stem cells, 
which constitute only a small fraction of the total population of tumor cells, are the only tumor cells capable of supporting tumor growth. Therefore, a scientific assumption was made that a complete cure for cancer may require the development of treatments targeting cancer stem cells, assuming that this can be accomplished without destroying the stem cells needed to maintain tissue regeneration, such as bone marrow and intestines (77). In addition, stem cells may be the source of some types of cancer, increasing the risk when used to repair organs, while they can also be of prognostic value as the proportion of stem cells in a tumor can determine how deadly it is.

Some therapeutic strategies for cancer treatment are focused on the destruction of cancer stem cells. However, many potential uses require stem cells to divide to produce enough cells to replace damaged tissue, a fact that could possibly contribute to the accumulation of potentially cancer-causing mutations (77). The origin of stem cells for some types of cancer means that these stem cells have telomerase that does not need to be reactivated, although the enzyme activity may be further increased in the later stages of carcinogenesis (78). On the contrary, the limited activity of telomerase, associated with the final lifespan of adult stem cells, can both contribute to aging and cancer prevention $(79,80)$.

Forced expression of telomerase (telomerization of cells). In many cell types, telomerase activity appears only after the forced expression of the hTERT gene, a process called telomerization. The RNA component of telomerase is expressed in most human cells regardless of telomerase activity; therefore, after the transfection of human cells with the hTERT gene, telomerase activity appears in them, and cells gain the ability to maintain TEL. Such cells are called telomerized. The presence of telomerase activity does not violate the mechanisms of cell growth regulation but it contributes to the stability of the genome, preventing chromosomal rearrangements instead. The sensitivity of telomerized and initial fibroblasts of adult skin to common cytostatics i.e., doxorubicin, cisplatin, etoposide, and dacarbazine was studied. No significant differences in sensitivity were found. These observations directly support the safekeeping of normal mechanisms of homeostasis in telomerized cells and indirectly support the assumption that they can be used in cell therapy (81).

Saretzki et al (82) (2004) found very similar molecular events in two unrelated human embryonic stem cell (hESC) lines that regulate the suppression of telomerase activity, increase oxidative stress, and decrease DNA repair activity during spontaneous differentiation. This study characterized resistance to oxidative stress and restoration of DNA breaks in parallel with the regulation of telomerase activity and TEL during differentiation of hESC. Previously, it was reported that murine ESC has a high level of antioxidant protection and effectively repair DNA chain breakage but the level of antioxidant protection and restoration of chain breakdown noticeably decrease during differentiation (82). The data obtained indicated the deacetylation of histones $\mathrm{H} 3$ and $\mathrm{H} 4$ in the hTERT promoter region. The deacetylation of histone $\mathrm{H} 3$ in the hTR promoter was suggested as a candidate mechanism for explaining the suppression of expression of both genes and the loss of telomerase activity during differentiation. Other studies have shown that histone modification is an important means of regulating telomerase gene expression $(83,84)$. The loss of telomerase activity is accompanied by a shortening of telomeres, which is especially fast in the early stages of differentiation. Telomere shortening can be accelerated due to high ROS levels since telomeres are at least partially deficient in repairing oxidative DNA damage (85). It was also shown that the self-renewing potential and longevity of HSCs in vivo are largely determined by the ROS levels (86).

Lonergan et al (87) (2006) suggested that mitochondrial characteristics may be an additional and reliable way to test stem cell competency. The results indicated that, the perinuclear arrangement of mitochondria in the primate stem cell line, accompanied by a low ATP/cell content and high oxygen consumption, may be a true indicator of competence in stem cell differentiation, and deviations from this profile suggest thaT cells differentiate or possibly age.

Passos et al (88) (2007) found in their studies that an increase in mitochondrial density in combination with mitochondrial dysfunction can accelerate aging. This is confirmed by a negative correlation between the density of mitochondria and the maximum life expectancy in interspecific comparisons in mammals. Strengthening mitochondrial biogenesis and, possibly, impaired mitochondrial degradation and segregation, if this occurs as an adaptation to pre-existing mitochondrial dysfunction, it can significantly increase ROS production and, thus, actively contribute to aging. In other words, both ATP and ROS production increase in parallel with the bulk density of mitochondria. In an aging organism, the mitochondrial mass and ROS production increase, while the membrane potential decreases due to the activation of the uncoupling protein (89).

A rather interesting result was obtained after the introduction of the hTERT gene into the cells of a patient suffering from Niemann-Pick C disease (NPC). NPC is a recessive lipidosis that is characterized by excessive accumulation of free cholesterol and glycosphingolipids in the endosomal lysosomal system. Walter et al (90) (2003) confirmed that ectopic expression of hTERT in human cells leads to increased regulation of small GTPase Rab9 and its p40 effector. Telomerase immortalization of human cells affects the function of the endosomal lysosomal system and in particular the efflux of cholesterol from this system, independently of the NPC1 protein. Such changes may be necessary to maintain cells in a continuous proliferative state $(90,91)$. In fact, a recent study has provided evidence for a correlation between cholesterol content and cell cycle progression (92). Inhibition of cholesterol biosynthesis with low concentrations of lovastatin blocked cell proliferation. When LDL-cholesterol was added to these cells, cell cycle progression resumed (92). In NPC1 disease, cells are unable to metabolize LDL-derived cholesterol due to its accumulation in the late endosomal lysosomal system. The expression of hTERT in NPC cells leads to the correction of the cell phenotype, including the elimination of the accumulated cholesterol. In particular, in NPC-TERT cells, cholesterol transport from the endosomal lysosomal system to the plasma membrane is restored with a concomitant increase in cholesterol esterification (90).

Transfection of cells with expression vectors containing hTERT supports TEL and provides normal cells with an unlimited life span in culture. It is important that hTERT 
prolongs the life span of cultured cells well beyond normal aging without causing a neoplastic transformation (93). Condon et al (93) developed a cell line from hTERT-infected human myometrial cells (hTERT-HM). Cells expressing telomerase contained mRNA for $\alpha$-smooth muscle actin, smoothelin, an oxytocin receptor, and an estrogen receptor $\alpha$. Myometrial cells immortalized with hTERT retained the differentiation markers that are observed in primary smooth muscle cell (SMC) cultures.

As known, the ectopic expression of hTERT prolongs the lifespan of certain human cells. McKee et al (94) (2003) introduced hTERT into human SMCs and found that the resulting cells proliferated well beyond their normal lifespan and, remarkably, retained the characteristics of normal control SMCs. Using these neonatal SMCs, they were able to create reliable human vessels, and then it becomes possible to create coronary arteries for coronary artery bypass grafting. Klinger et al (95) (2006) concluded that this tissue engineering model emphasizes the effect of donor age on cellular synthetic function, which apparently does not depend on the increase in hTERT life span.

Chronic stress exposure and telomerase activity. PB mononuclear cells (PBMCs), are most suitable for the study of telomerase activity. Maximow (96) (1909), the founder of the stem cell theory, revealed that PBMCs are stem cells that are common to various blood elements in embryonic development and during the fetal life in mammals. It has been shown that there is an accelerated telomere shortening and reduced telomerase activity in PBMC in various situations. Recent studies have shown changes in TEL and telomerase activity due to psychological and social factors (64). An earlier study showed that telomere shortening and the decrease in the telomerase activity is higher in PBMC of women with high stress levels compared with the control group (24). This study initiated a large number of similar studies, showing that telomeres are shorter in patients with mood disorders (97), in hemodialysis-depended patients (98) and in patients with depressive disorder (99).

To date, the effect of chronic stress on telomerase activity in humans has been described in many studies $(68,100-102)$. This effect includes an increase in the oxidative level, which stimulates hTERT nuclear export to the cytosol and decreases the nuclear and total telomerase activity $(62,103,104)$. It has been observed that long periods of psychological stress can increase vulnerability to the effects of the virus that induces aging of specific $\mathrm{T}$ cells (32).

According to Lansdorp (105) (2006), telomere shortening can be due to the influence of psychological stress and social rank, whereas Adams et al (106) (2007) contradict the theory that socio-economically deprived people age faster and, therefore, have shorter telomeres than the more affluent part of society. Chronic stress can affect human health through a variety of behavioural aspects and biochemical pathways (107). The shortening of telomeres in cells of the immune system occurs through biochemical reactions (108), while stress can also affect the occurrence of age-related diseases (109). It has been shown that metabolic stress plays an important role in telomere shortening and that the decrease in the level of $\omega-3$ fatty acids in the blood correlates with telomeres and may be a marker of aging (110). Moreover, chronic stress and depression are directly related to high levels of hydroxy-deoxyguanosine and reduced levels of antioxidant enzymes $(111,112)$. In addition, oxidative stress affects telomeres more frequently compared to other areas of genomic DNA and inhibits telomerase activity in vitro in various cell types $(113,114)$.

An antioxidant function is associated with various micronutrients, including vitamin C, E, folic acid, and $\omega-3$ fatty acids and, therefore, can positively affect TEL (115). Stress leads to having high levels of pro-inflammatory cytokines, including IL-6 and TNF- $\alpha(116,117)$.

Insulin-like growth factor 1 (IGF-1) exerts a mitogenic effect implicated in cell proliferation. It was first reported that IGF-1 is involved in the modulation of telomerase activity by enhancing the stimulation of telomerase activity caused by phytohemagglutinin (PHA) in cord blood mononuclear cells, which have characteristically low levels of telomerase activity and hTERT expression $(118,119)$.

Fibroblast growth factor 2 (FGF2) has been shown to induce a dose-dependent increase in both neural precursor cell proliferation and telomerase activity in primary cortical cultures $(118,120)$. In contrast, in both neurons and glial cells in primary cultures of E15 mouse embryo cortex, down-regulation of telomerase activity and mTERT gene expression occurred in parallel with cell differentiation (120). In primary endothelial cells, freshly isolated from intact endothelium, telomerase activity is observable during logarithmic growth but not when cells enter quiescence (121). Treatment of quiescent human umbilical vein endothelial cells (HUVECs) with FGF2 reactivates telomerase activity in a time- and dose-dependent manner, in contrast to vascular endothelial growth factor-A (VEGF-A), which has no effect (121). Consistently, FGF2 but not VEGF-A, up-regulates hTERT expression in parallel with transcription factor Sp1 (121).

VEGF has angiogenic activity that can contribute to tumor development by inducing vessel permeability that facilitates tumor cell proliferation and metastasis (122). Although VEGF-A appears not to regulate telomerase activity in human umbilical vein endothelial cells (123), VEGF and lysophosphatidic acid (LPA), both secreted from ovarian cancer cells and known to promote cancer cell growth, have been shown to regulate telomerase activity in non-endothelial cells $(118,124)$. Up-regulation of telomerase activity by VEGF appears to be receptor-dependent, as unsaturated vitamin $\mathrm{E}$, tocotrienol, has been shown to down-regulate telomerase activity through down-regulating the VEGF receptor (125). Vitamin E has also been reported to down-regulate telomerase activity in ovarian cancer cells $(118,126)$.

Genetic factors are also related to telomere shortening. Monoamine oxidase-A and apolipoprotein E (APOE) polymorphisms were statistically significant for TEL only in people with mental and depressive disorders but not in healthy respondents. In addition, sex, the APO- $\varepsilon 2$ allele, and the polymorphism of the monoamine oxidase-A have an indirect effect on TEL. Thus, mental and depressive disorder is an additional mediator between monoamine oxidase-A and APOE polymorphisms and TEL (99). Further, studies revealed similar patterns in the European population for the APOE- $\varepsilon 4$ gene polymorphism, which is associated with a risk of Alzheimer's 
disease. Although telomeres are shortened significantly faster in female carriers of the APOE- $\varepsilon 4$ mutant allele, hormone replacement therapy in middle-aged women can change the effect of allele transfer on aging (127).

In order to explain the effect of chronic stress on telomere shortening, Damjanovic et al (128) (2007) studied immunological changes in caregivers for relatives with Alzheimer's disease. TEL was significantly shorter in caregivers than in control subjects and their immune response was weaker. Moreover, caregivers had significantly lower $\mathrm{T}$ cell proliferation but higher production of immunoregulatory cytokines (TNF- $\alpha$ and IL-10) than control subjects in response to in vitro stimulation. These results demonstrate that chronic stress leads to a reduction in TEL and is associated with accelerated aging of T-cells.

However, there is some controversy among different studies on telomere shortening under stress conditions. Effros (129) (2001) proposed an interesting model for the study of PB cells in vitro, where lymphocytes from healthy donors, namely men and women aged 25-55 years, were exposed to various concentrations of cortisol, which is a stress-related hormone or dimethyl sulfoxide. He showed that the level of telomerase activity decreases under stress, which explains the decrease in both the number of immune-competent $\mathrm{T}$ cells and the length of telomeres in these cells under chronic stress, further accelerating cell aging and deterioration of the immune system $(130,131)$.

Ornish et al (132) (2008) investigated for three months the comprehensive lifestyle changes for 30 men with biopsy-diagnosed low-risk prostate cancer, which led to a significant increase in telomerase activity by $10 \%$. Increased telomerase activity was associated with a decrease in the level of low-density lipoprotein cholesterol (LDL) and a decrease in psychological stress. Physical activity appears to protect against metabolic and psychological stress and maintain TEL (133). Moreover, a study on various diets showed that chronic food restriction (regardless of age), body mass index, or smoking might be a risk factor for telomere premature shortening (134). Furthermore, regular sleep, exercise, and a healthy lifestyle contribute to normal TEL and telomerase activity, regardless of the level of the depressive disorder on the Hamilton Depression Rating Scale (135). These data are consistent with the results of another study, which showed that the effectiveness of an antidepressant depends on the initial level of telomerase activity (136). In addition, De Punder et al (137) (2018) recently reported that high levels of chronic stress reduce the ability of immune cells to induce telomerase activity by $25 \%$ compared to moderate or low levels of chronic stress. Chronic stress is associated with a decrease in mitogen-induced lymphocyte proliferation and mitogen-induced IL-2 production (138), which are activators of signalling pathways that stimulate telomerase activity $(139,140)$. Chronic stress exposure is also associated with a higher level of oxidative stress, which ultimately leads to the accumulation of senescent (CD28-) T-cells (103). This suggests stringent telomerase regulation in human T cells, which may contribute to telomere shortening and ultimate replicative potential and loss of control over certain pathogens (141).

In conclusion, the length of telomeres in PB cells can be an indicator of human health, stress resistance, and cell adaptation. Accordingly, changes in TEL and telomerase activity may reflect the effectiveness of the treatment of age-related diseases. Most of the recent studies on telomeres and age-related diseases are based on the fact that increase in telomerase activity corresponds to either a decrease in telomere shortening (30), or telomere elongation (142).

EffectofTEL on fertility and pregnancy. Vasilopoulos et al(143) (2019) investigated the potential relationship between TEL and various factors of female and male infertility. Most female infertility factors have been associated with shorter TEL, with the exception of endometriosis, premature ovarian failure, transparent cell carcinoma, and polycystic ovary syndrome (PCOS). These types of diseases have been associated with a longer TEL, which has shown conflicting results in several studies. On the other hand, male infertility factors were associated with critically shorter TEL (143).

Fragkiadaki et al (144) (2016) summarized and critically discussed the evidence linking telomerase activity with pregnancy complications. Maternal age is a determining factor in fertilization success and numerous studies have focused on telomerase activity and its correlation with mammalian fertilization, as well as subsequent splitting processes and preimplantation development. It has been also shown that there is a relationship between telomerase activity and complications during pregnancy.

Additionally, the effect of psychosocial stress on pregnancy is an important risk factor for the early onset of common age-related diseases (145). Human studies have demonstrated a link between chronic or excessive psychosocial stress and telomere biology (146). It was shown that stress-related changes in telomeres might be a possible mechanism linking psychosocial stress with age-related diseases (147). Indeed, the accelerated shortening of telomeres reflects stress-induced oxidative cell damage and accelerated aging (97). Therefore, Lazarides et al (148) (2019) examined the hypothesis that the maternal pro-inflammatory state during pregnancy, which is a balance between TNF- $\alpha$, the main pro-inflammatory cytokine, and IL-10, the main anti-inflammatory cytokine, are directly related to the TEL of the leukocytes (LTL) of the newborn at birth. The higher average ratio of TNF- $\alpha / \mathrm{IL}-10$ during pregnancy was significantly associated with shorter TEL of the newborn after adjusting for the mother's age, body mass index before pregnancy and sex of the child.

Effect of nutraceutical supplements on TEL. The Dietary Inflammatory Index (DII) was developed by Shivappa et al (2014) to measure the inflammatory potential of diet and it can be used in diverse populations to predict levels of inflammatory markers, including C-reactive protein (CRP) and interleukin-6 (149-151). Shivappa et al (152) (2017) examined whether inflammatory potential of diet, as measured by the Dietary Inflammatory Index (DII) has an impact on telomere shortening in the National Health and Nutrition Examination Survey (NHANES). Validation of the DII with $\mathrm{C}$-reactive protein (CRP) was also carried out, showing that there was an association between DII and leukocyte TEL in these NHANES data. The impact of specific fatty acids on inflammation can be crucial to the effect of dietary fats on human health, for example polyunsaturated fatty acids, 
mainly $\omega-3$ fatty acids, have anti-inflammatory and immunomodulating properties. Research studies have confirmed that excessive amounts of $\omega-6$ fatty acids leading to a high $\omega-6$ : $\omega-3$ fatty acid ratio can promote the pathogenesis of chronic diseases (153). Interestingly, a Mediterranean diet supplemented with two fatty fish meals per week, rich in $\omega-3$ fatty acids, has been shown to have an anti-inflammatory effect reducing airway inflammation in childhood asthma that is a chronic disease (154). Therefore, it is likely that blood polyunsaturated fatty acid levels are involved in preventing telomere shortening over time (155). In agreement with this, recent studies revealed that the administration of nutraceutical supplements to healthy individuals is implicated in TEL maintenance (156). Participants were selected from healthy outpatients and divided into an intervention group that received nutraceutical supplements and a control group. The length of individual telomeres was estimated in metaphase leukocytes isolated from PB using Q-FISH analysis. The median length of the telomeres was significantly increased $(\mathrm{P}<0.05)$ in the intervention group compared with the control group. The beneficial effect of supplements on the length of short telomeres was significant $(\mathrm{P}<0.05)$ after correction for age and sex, suggesting that nutraceutical supplements can directly affect the maintenance of TEL.

\section{Chronographic theory of aging: Neural chronograph}

As mentioned, Olovnikov (1973) described the 'problem of insufficient replication' in the 1970s and predicted that in the case of the matrix synthesis of a linear polynucleotide (chromosome replication), the copy should be shorter and the limitation of the number of cell divisions is associated with this fact (19). This led him to construct a new theory of aging $(160,161)$. It has been proposed that if development and aging are programmed, then some 'watch' mechanism that controls aging is required (67,162-165). Biorhythms are often called clocks, and genes involved in rhythms, usually circadian rhythms, are referred to as clock genes. But is there a real timekeeping mechanism in the body that would organize, register, and track physiological changes according to the age of the body? Olovnikov bases his theory on the idea of the controlled loss of neurons in the brain of hypothetical organelles, called chronomeres, which represent small DNA molecules that were amplified from chromosomal DNA segments $(162,163)$.

Chronographic theory of development and aging. A biochronograph to describe the development, aging, and longevity of a certain species, should consider that some genes have probably changed their expression in different species and in different age groups. In C. elegans, for instance, a relatively small number of genes show significant changes in transcript levels as they age ( $<1 \%$ of the genome) (166). Comparison of the results of the $C$. elegans shows sets of overlapping genes that are highly conserved throughout evolution and appear to be genes that actually control aging and lifespan $(167,168)$. Herndon et al (169) (2002) found convincing evidence that stochastic as well as genetic factors are important in aging C.elegans, with extensive variability between cells of the same type within individuals. Moreover, the timing of gene expression of adult Drosophila is regulated by independent mechanisms related to temperature and metabolic rate. Studies of relative temporary scaling at long-living mutants of C.elegans showed that the life expectancy is controlled by some physiological hours different from chronological time (170).

Olovnikov (171) (2007) claims that the lunar cycle plays a role in aging of living organisms. He suggested that pineal cells called pinealotcytes regularly change the endocrine secretory activity, responding to periodic changes of the gravitational field of the moon. The theory is based on the idea of a controlled loss by a neuron in the brain of chronomeres. The regular process of loss of chronomeres in neurons is controlled by the pineal gland and activated at least once a lunar month. Hormonal signals can be generated by the pineal gland and depend on the gravity of the periodic shift of the mineralized deposits located at the intra-pinealotcyte of neighbour cellular structures. The calcific large particles that are in extracellular spaces of a pineal gland can also contribute to the hormonal secretion.

This pineal secretion activates the hypothalamus, enhancing the hormonal response, which allows a sharp increase in the concentration of several hormones, the so-called T-signal. The T-signal is a 'hormonal intracerebral explosion' that happens in humans every month and is a kind of hormonal combination, which can enhance transcription in brain cells. Under certain conditions, the chronomeres in response to a T-signal can lose each neuron performing temporary functions, and as a result, the neuron changes the activity. As mentioned above, chronomeres are hypothetical mini-organelles that are present in the neurons performing temporary functions, including counting time and participating in the control of the biological age of an organism. Chronomere is a perichromosomal copy of the chromosomal original, a rather small two-chained DNA molecule, which is protected by proteins. Thus, each chronomere is on a surface of a chromosome and is levelled along this segment of chromosomal DNA, which serves as the original for this chronomere. Chronomere DNA contains various regulatory sequences (171).

Adjusting the sensitivity of endocrine gravity sensors in different species of vertebrates may be one of the key factors responsible for the rate of embryonic development in each species of vertebrate. Gradual suppression of inhibitors is very important for embryonic brain development $(172,173)$. Changes in functional inhibitory interactions are necessary for the maturation of the prefrontal cortex when the cerebral cortex is connected (174). Epigenetic suppression of key inhibitory loci may play a fundamental role in the initiation of puberty (175). When the maturation of the body is complete, clusters of neurons remain in the brain, which are essentially the endpoint of the time relay, while the temporary neurons of these clusters contain only terminal chronomeres, which gradually decrease. The greater the reserves of such neurons, the longer the lifetime is, considering that all other things are equal, which could be the reason why life expectancy is positively correlated with the cephalization index (176).

Age-related changes in the human brain as a possible outcome of the chronomere's function. Dedifferentiation of brain cells is used as a means of development and loss of control and dedifferentiation of neurons is found in several pathologies (177). However, changes in the brain must also occur 
during normal development. Dedifferentiation or decreased treatment specificity is a robust characteristic of cognitive aging. Voss et al proved that neural dedifferentiation was not ubiquitous in different categories of stimuli, while nervous dedifferentiation was relatively stable according to the age of the elderly $(178,179)$. Moreover, an age-related decline in specialization has also been shown for the cognitive function of the frontal lobes of the hemispheres (180). Dreher et al examined the relationship between dopamine synthesis in the midbrain and the prefrontal ligament with reward. It was found that healthy aging causes functional changes in the reward system, and reveals age-related changes in the relationship between dopamine synthesis in the midbrain and prefrontal activity. These results gave insight into the interaction between dopamine function of the midbrain and the reward system in young people and the elderly, and also determined the changes that accompany aging (181). Furthermore, it has been shown that the contraction of the hippocampus, inferior temporal cortex and prefrontal white matter are increased with age, while shrinkage in the hippocampus and cerebellum accelerates $(182,183)$. The weakening of the functional correlations of individual parts of the brain spreads with age from the forehead to the back of the head (184).

The decrease in the volume of a brain becomes noticeable approximately from 30 years of age (185). Total brain volume for mentally healthy people is steadily declining by $0.22 \%$ per year between 20 and 80 years, and this decrease is accelerated in older age (186). The brain in some patients has vital deposits of amyloid protein indicative of the preclinical phase of Alzheimer's disease: Their brain volume is reduced by $2.5 \%$ compared with the brain of healthy volunteers. All of the listed age-related changes, including a decrease in brain volume, are considered a result of aging caused by various factors, among which is the accumulation of damage caused by free radicals. However, qualitative changes in the brain can be interpreted in a completely different way, meaning that all these changes in the brain are not the result of errors, but the product of genetic programming.

\section{Conclusions and future research directions}

As discussed in this review, telomerase activity is regulated in response to various biological factors and systems, including stress hormones, oxidative stress, inflammatory mediators, and circadian rhythm. Therefore, future studies of telomerase activity in PB mononuclear cells should include measurements of biomarkers that participate in these processes, which will significantly contribute to enhancing our knowledge in the field. Moreover, it is necessary to further study the role of telomerase in the defence mechanism of mitochondria against oxidative stress to gain a broader understanding of the role of telomerase in human health and the risk of stress-related diseases.

A decrease in telomerase activity may explain why telomeres shorten faster under pathological conditions. The study and characterization of individual differences in the ability of the telomere biology system to respond to a challenge, in addition to indicators of basal telomerase activity and TEL, is an interesting non-standard approach for future studies of telomere biology and aging.

\section{Acknowledgements}

The authors would like to thank Dr Muhammad Amjad Nawaz from SEC of Nanotechnology, Far Eastern Federal University (Vladivostok, Russia) for his assistance with the copy-editing of the manuscript and for correcting the final proofs.

\section{Funding}

This study was supported by Spin-Off Toxplus S.A. and by the Special Research Account of University of Crete (ELKE nos. 4602, 4920 and 3963).

\section{Availability of data and materials}

Not applicable.

\section{Authors' contributions}

All the authors contributed in conceiving and designing the study. MPR, AMZ and KSG searched the literature for inclusion in the study and wrote the manuscript. MT, ES, and PF checked and reviewed the manuscript. KN, DT, DAS, and AT gave advice and critically revised the manuscript. All authors have read and approved the final version of the manuscript.

\section{Ethics approval and consent to participate}

Not applicable.

\section{Patient consent for publication}

Not applicable.

\section{Competing interests}

DAS is the Editor-in-Chief for the journal, but had no personal involvement in the reviewing process, or any influence in terms of adjudicating on the final decision, for this article. The other authors declare that they have no competing interests.

\section{References}

1. Morgan TH: Random segregation versus coupling in Mendelian inheritance. Science 34: 636-638, 1911.

2. McClintock B: Cytological observations of deficiencies involving known genes, translocations and an inversion in Zea mays. Mo Agric Exp Res Stn Res Bull 163: 1-30, 1931.

3. Möller HJ: The remaking of chromosomes. Collecting Net 8: 182-198, 1938.

4. Blackburn EH and Gall JG: A tandemly repeated sequence at the termini of the extrachromosomal ribosomal RNA genes in Tetrahymena. J Mol Biol 120: 33-53, 1978.

5. De Lange T, Lundblad V and Blackburn EH (eds): Telomeres. Cold Spring Harbor Laboratory Press, New York, NY, pp21-48, 2006.

6. Hsu TC, Arrighi FE and Saunders GF: Compositional heterogeneity of human heterochromatin. Proc Natl Acad Sci USA 69: 1464-1466, 1972.

7. Watson JD: Origin of concatemeric T7 DNA. Nat N Biol 239: 197-201, 1972.

8. Olovnikov AM: The principle of marginotomy in the matrix synthesis of polynucleotides. Dokl Akad Nauk SSSR 201: 1496-1499, 1971. 
9. Shay JW and Wright WE: Telomerase activity in human cancer. Cur Opin Oncol 8: 66-71, 1996.

10. Bodnar AG, Ouellette M, Frolkis M, Holt SE, Chiu CP, Morin GB, Harley CB, Shay JW, Lichtsteiner S and Wright WE: Extension of life-span by introduction of telomerase into normal human cells. Science 279: 349-352, 1998.

11. Martin M: The biology of aging: 1985-2010 and beyond. FASEB J 25: 3756-3762, 2011.

12. Thanasoula M, Escandell JM, Martinez P, Badie S, Muñoz P, Blasco MA and Tarsounas M: p53 prevents entry into mitosis with uncapped telomeres. Curr Biol 20: 521-526, 2010.

13. Thanasoula M, Escandell JM, Suwaki N and Tarsounas M: ATM/ATR checkpoint activation downregulates CDC25C to prevent mitotic entry with uncapped telomeres. EMBO J 31: 3398-3410, 2012.

14. Tejera AM, Stagno d'Alcontres M, Thanasoula M, Marion RM, Martinez P, Liao C, Flores JM, Tarsounas M and Blasco MA: TPP1 is required for TERT recruitment, telomere elongation during nuclear reprogramming, and normal skin development in mice. Dev Cell 18: 775-789, 2010.

15. Martínez $\mathrm{P}$, Thanasoula M, Muñoz P, Liao C, Tejera A, McNees C, Flores JM, Fernández-Capetillo O, Tarsounas M and Blasco MA: Increased telomere fragility and fusions resulting from TRF1 deficiency lead to degenerative pathologies and increased cancer in mice. Genes 23: 2060-2075,2009.

16. Hayflick L and Moorhead PS: The serial cultivation of human diploid cell strains. Exp Cell Res 25: 585-621, 1961.

17. Lehman IR, Bessman MJ, Simms ES and Kornberg A: Enzymatic synthesis of deoxynucleic acid. I. Preparation of substances and partial purification of an enzyme from Escherichia coli. J Biol Chem 233: 163-170, 1958

18. Bessman MJ, Lehman IR, Simms ES and Kornberg A: Enzymatic synthesis of deoxynucleic acid. II. General properties of the reaction J Biol Chem 233: 171-177, 1958.

19. Olovnikov AM: A Theory of marginotomy. The incomplete copying of template margin in enzymic synthesis of poly nucleotides and biological significance of the phenomenon. $J$ Theor Biol 41: 181-190, 1973.

20. Greider CW and Blackburn EH: The telomere terminal transferase of tetrahymena is a ribonucleoprotein enzyme with 2 kinds of primer specificity. Cell 51: 887-898, 1987.

21. Harley CB, Vaziri H, Counter CM and Allsop RC: The telomere hypothesis of cellular aging. Exp Gerontol 27: 375-382, 1992

22. Greider CW and Blackburn EH: Telomeres, telomerase and cancer. Sci Am 274: 92-97, 1996.

23. Chan SRWL and Blackburn EH: Telomeres and telomerase. Philos Trans R Soc Lond B Biol Sci 359: 109-121, 2004.

24. Epel ES, Blackburn EH, Lin J, Dhabha FS, Adler NE, Morrow JD and Cawthon RM: Accelerated telomere shortening in response to life stress. Proc Natl Acad Sci USA 101: $17312-17315,2004$

25. Osterhage JL and Friedman KL: Chromosome end maintenance by telomerase. J Biol Chem 284: 16061-16065, 2009.

26. Yudoh K, Matsuno H, Nezuka T and Kimura T: Different mechanisms of synovial hyperplasia in rheumatoid arthritis and pigmented villonodular synovitis: The role of telomerase activity in synovial proliferation. Arthritis Rheum 42: 669-677, 1999.

27. Hiyama E and Hiyama K: Telomere and telomerase in stem cells Br J Cancer 96: 1020-1024, 2007.

28. Fujii H, Shao L, Colmegna I, Goronzy JJ and Weyand CM: Telomerase insufficiency in rheumatoid arthritis. Proc Natl Acad Sci USA 106: 4360-4365, 2009.

29. Katayama $\mathrm{Y}$ and Kohriyama K: Telomerase activity in peripheral blood mononuclear cells of systemic connective tissue diseases. J Rheumatol 28: 288-291, 2001.

30. Georgin-Lavialle S, Aouba A, Mouthon L, Londono-Vallego JA, Lepelletier Y, Gabet AS and Hermine O: The telomere/telomerase system in autoimmune and systemic immune-mediated diseases. Autoimmun Rev 9: 646-651, 2010.

31. Vakonaki E, Tsiminikaki K, Plaitis S, Fragkiadaki P, Tsoukalas D, Katsikantami I, Vaki G, Tzatzarakis MN, Spandidos DA and Tsatsakis AM: Common mental disorders and association with telomere length. Biomed Rep 8: 111-116, 2018.

32. Akbar AN and Vukmanovic-Stejic M: Telomerase in T lymphocytes: Use it and lose it? J Immunol 178: 6689-6694, 2007.

33. Tomlinson RL, Ziegler TD, Supakorndej T, Terns RM and Terns MP: Cell cycle-regulated trafficking of human telomerase to telomeres. Mol Biol Cell 17: 955-965, 2006.
34. Ksiazek K, Passos JF, Olijslagers S, Saretzki G, Martin-Ruiz C and von Zglinicki T: Premature senescence of mesothelial cells is associated with non-telomeric DNA damage. Biochem Biophys Res Commun 362: 707-711, 2007.

35. Yeager TR, Neumann AA, Englezou A, Huschtscha LI, Noble JR and Reddel RR: Telomerase-negative immortalized human cells contain a novel type of promyelocytic leukemia (PML) body. Cancer Res 59: 4175-4179, 1999.

36. Bryan TM, Englezou A, Gupta J, Bacchetti S and Reddel RR: Telomere elongation in immortal human cells without detectable telomerase activity. EMBO J 14: 4240-4248, 1995.

37. Perrem K, Colgin LM, Neumann AA, Yeager TR and Reddel RR: Coexistence of alternative lengthening of telomeres and telomerase in hTERT-transfected GM847 cells. Mol Cell Biol 21: 3862-3875, 2001.

38. Dunham MA, Neumann AA, Fasching CL and Reddel RR: Telomere maintenance by recombination in human cells. Nat Genet 26: 447-450, 2000.

39. Varley H, Pickett HA, Foxon JL, Reddel RR and Royle NJ: Molecular characterization of inter-telomere and intra-telomere mutations in human ALT cells. Nat Genet 30: 301-305, 2002.

40. Cesare AJ and Reddel RR: Alternative lengthening of telomeres: Models, mechanisms and implications. Nat Rev Genet 11: 319-330, 2010.

41. Zencir S, Hsieh MH, Hsu JS, Ergun Y, Chou GL, Li TK, Teng SC and Topcu Z: Selected Ellipticine derivatives, known to target topoisomerase II, suppress the alternative lengthening of telomere (ALT) pathway in telomerase-negative cells. J Cancer Res Clin Oncol 146: 1671-1676, 2020.

42. Kashubowska L: Telomere shortening and ageing of immune systems. J Physiol Pharmacol 59: 169-186, 2008.

43. Klapper W, Moosig F, Sotnikova A, Qian W, Schroeder JO and Parwaresch R: Telomerase activity in $\mathrm{B}$ and $\mathrm{T}$ lymphocytes of patients with systemic lupus erythematosus. Ann Rheum Dis 63: $1681-1683,2004$

44. Blinova EA, Zinnatova EV, Barkovskaya MSh, Borisov VI, Sizikov AE, Kozhevnikov VS, Rubtsov NB and Kozlov VA: Telomere length of individual chromosomes in patients with rheumatoid arthritis. Bull Exp Biol Med 160: 779-782, 2016.

45. Lin J, Xie J and Qian WB: Telomerase activity and telomere length in $\mathrm{CD}^{+}, \mathrm{CD} 8^{+}$and $\mathrm{CD} 19^{+}$lymphocytes from patients with systemic lupus erythematosus. Zhejiang Da Xue Xue Bao Yi Xue Ban 34: 534-537, 2005 (In Chinese).

46. Wu K, Higashi N, Hansen ER, Lund M, Bang $\mathrm{K}$ and Thestrup-Pedersen K: Telomerase activity is increased and telomere length shortened in T-cells from blood of patients with atopic dermatitis and psoriasis. J Immunol 165: 4742-4747, 2000.

47. Bishop NA, Lu T and Yankner BA: Neural mechanisms of ageing and cognitive decline. Nature 464: 529-535, 2010.

48. Sun N, Youle RJ and Finkel T: The mitochondrial basis of aging. Mol Cell 61: 654-666, 2016.

49. Vyas S, Zaganjor E and Haigis MC: Mitochondria and cancer Cell 166: 555-566, 2016

50. Wallace D: Mitochondria and cancer. Nat Rev Cancer 12: 685-698, 2012

51. Kausar S, Wang F and Cui H: The role of mitochondria in reactive oxygen species and its implications for neurodegenerative diseases. Cells 7: 274, 2018.

52. Lane $\mathrm{N}$ and Martin W: The energetics of genome complexity. Nature 467: 929-934, 2010

53. Anderson S, Bankier AT, Barrell BG, de Bruijn MH, Coulson AR, Drouin J, Eperon IC, Nierlich DP, Roe BA, Sanger F, et al: Sequence and organization of the human mitohondrial genome. Nature 290: 457-465, 1981.

54. Ojala D, Montoya J and Attardi G: tRNA punctuation model of RNA processing in human mitochondria. Nature 290: 470-471, 1981.

55. Nagaike T, Suzuki T, Katoh T and Ueda T: Human mitochondrial mRNAs are stabilized with polyadenylation regulated by mitochondria-specific poly(A) polymerase and polynucleotide phosphorylase. J Biol Chem 280: 19721-19727, 2005.

56. Zhang X, Zuo X, Yang B, Li Z, Xue Y, Zhou Y, Huang J, Zhao X, Zhou J, Yan Y, et al: MicroRNA directly enhances mitochondrial translation during muscle differentiation. Cell 8: 607-619, 2014.

57. Jacquier A: The complex euaryotic transcriptome: Unexpected pervasive transcription and novel small RNAs. Nat Rev Genet 10: 833-844, 2009.

58. Artlett CM, Black CM, Briggs DC, Stevens CO and Welsh KI: Telomere reduction in scleroderma patients: A possible cause for chromosomal instability. Br J Rheumatol 35: 732-737, 1996. 
59. Mercer TR, Neph S, Dinger ME, Crawford J, Smith MA, Shearwood AM, Haugen E, Bracken CP, Rackham O, Stamatoyannopoulos JA, et al: The human mitochondrial transcriptome. Cell 146: 645-658, 2011.

60. Wang G, Chen HW, Oktay Y, Zhang J, Allen EL, Smith GM Fan KC, Hong JS, French SW and McCaffery JM: PNPASE regulates RNA import into mitochondria. Cell 142: 456-467, 2010 .

61. Cheng Y, Liu P, Zheng Q, Gao G, Yuan J, Wang P, Huang J, Xie L, $\mathrm{Lu} \mathrm{X}$, Tong T, et al: Mitochondrial trafficking and processing of telomerase RNA TERC. Cell Rep 24: 2589-2595, 2018.

62. Haendeler J, Hoffmann J, Diehl JF, Vasa M, Spyridopoulos I, Zeiher AM and Dimmeler S: Antioxidants inhibit nuclear export of telomerase reverse transcriptase and delay replicative senescence of endothelial cells. Circ Res 94: 768-775, 2004.

63. Santos JH, Meyer JN, Skorvaga M, Annab LA and Van Houten B: Mitochondrial hTERT exacerbates free-radical-mediated mtDNA damage. Aging Cell 3: 399-411, 2004.

64. De Punder K, Heim C, Wadhwa PD and Entringer S: Stress and immunosenescence: The role of telomerase. Psychoneuroendocrinology 101: 87-100, 2019.

65. Vickers M, Brown GC, Cologne JB and Kyoizumi S: Modelling heaemopoietic stem cell division by analysis of mutant red cells. Br J Haematol 2000: 54-62, 2000.

66. Greenwood MJ and Lansdorp PM: Telomeres, telomerase, and hematopoietic stem cell biology. Arch Med Res 34: 489-495, 2003.

67. RuferN, BrümmendorfTH,Kolvraa S, Bischoff C, Christensen K, Wadsworth L, Schulzer M and Lansdorp PM: Telomere fluorescence measurements in granulocytes and $\mathrm{T}$ lymphocyte subsets point to a high turnover of hematopoietic stem cells and memory T cells in early childhood. J Exp Med 190: 157-167, 1999.

68. Verfaillie CM, Pera MF and Lansdorp PM: Stem cells: Hype and reality. Hematology Am Soc Hematol Educ Program 2002: 369-391, 2002

69. Wynn RF, Cross MA, Hatton C, Will AM, Lashford LS, Dexter TM and Testa NG: Accelerated telomere shortening in young recipients of allogeneic bone-marrow transplants. Lancet 351: 178-181, 1998.

70. Scheding S, Ersöz I, Hartmann U, Bartolvic K, Balabanov S Salama A, Kanz L and Brümmendorf TH: Peripheral blood cell telomere length measurements indicate that hematopoietic stem cell turnover is not significantly increased in whole blood and apheresis PLT donors. Transfusion 43: 1089-1095, 2003

71. Weng NP, Levine BL, June CH and Hodes RJ: Human naive and memory T lymphocytes differ in telomeric length and replicative potential. Proc Natl Nat Acad Sci USA 92: 11091-11094, 1995.

72. Jiang Y, Jahagirdar BN, Reinhardt RL, Schwartz RE, Keene CD, Ortiz-Gonzalez XR, Reyes M, Lenvik T, Lund T, Blackstad M, et al: Pluripotency of mesenchymal stem cells derived from adult marrow. Nature 418: 41-49, 2002.

73. Simonsen JL, Rosada C, Serakinci N, Justesen J, Stenderup K, Rattan SI, Jensen TG and Kassem M: Telomerase expression extends the proliferative life-span and maintains the osteogenic potential of human bone marrow stromal cells. Nat Biotechnol 20 592-596, 2002

74. Shi S, Gronthos S, Chen S, Reddi A, Counter CM, Robey PG and Wang CY: Bone formation by human postnatal bone marrow stromal stem cells is enhanced by telomerase expression. Nat Biotechnol 20: 587-591,2002.

75. Satija NK, Gurudutta GU, Sharma S, Afrin F, Gupta P, Verma YK, Singh VK and Tripathi RP: Mesenchymal stem cells: Molecular targets for tissue engineering. Stem Cells Dev 16: 7-23, 2007.

76. Lessard J and Sauvageau G: Bmi-1 determines the proliferative capacity of normal and leukaemic stem cells. Nature 423 255-260, 2003

77. Marx J: Cancer research. Mutant stem cells may seed cancer. Science 301: 1308-1310, 2003.

78. Armanios $\mathrm{M}$ and Greider CW: Telomerase and cancer stem cells Cold Spring Harb Symp Quant Biol 70: 205-208, 2005.

79. Zimmermann S and Martens UM: Telomeres, senescence, and hematopoietic stem cells. Cell Tissue Res 331: 79-90, 2008

80. Kuhn G, Brustle O, Martens U, Wobus A and Unsicker K: Stem cells: Established facts, open issues, and future directions. Cell and Tissue Res 331: 1-3, 2008

81. Yegorov YE, Vishnyakova KS, Terekhov SM and Zelenin AV: Telomerization of diploid fibroblasts does not lead to substantial changes in cell sensitivity to common cytostatics. Biologicheskie Membrany 23: 370-375, 2006.
82. Saretzki G, Armstrong L, Leake A, Lako M and von Zglinicki T Stress defense in murine embryonic stem cells is superior to that of various differentiated murine cells. Stem Cells 22: 962-971, 2004.

83. Atkinson SP, Hoare SF, Glasspool RM and Keith WN: Lack of telomerase gene expression in alternative lengthening of telomere cells is associated with chromatin remodeling of the hTR and hTERT gene promoters. Cancer Res 65: 7585-7590, 2005

84. Serakinci N, Hoare SF, Kassem M, Atkinson SP and Keith WN Telomerase promoter reprogramming and interaction with general transcription factors in the human mesenchymal stem cell. Regen Med 1: 125-131, 2006.

85. Richter T, Saretzki G, Nelson G, Melcher M, Olijslagers S and von Zglinicki T: TRF2 overexpression diminishes repair of telomeric single-strand breaks and accelerates telomere shortening in human fibroblasts. Mech Ageing Dev 128: 340-345, 2007.

86. Ito K, Hirao A, Arai F, Takubo K, Matsuoka S, Miyamoto K, Ohmura M, Naka K, Hosokawa K, Ikeda Y and Suda T: Reactive oxygen species act through p38 MAPK to limit the lifespan of hematopoietic stem cells. Nat Med 12: 446-451, 2006.

87. Lonergan T, Brenner C and Bavister B: Differentiation-related changes in mitochondrial properties as indicators of stem cell competence. J Cell Physiol 208: 149-153, 2006.

88. Passos JF, von Zglinicki T and Kirkwood TB: Mitochondria and ageing: Winning and losing in the numbers game. Bioessays 29 908-917, 2007

89. Lee HC, Yin PH, Chi CW and Wei YH: Increase in mitochondrial mass in human fibroblasts under oxidative stress and during replicative cell senescence. J Biomed Sci 9: 517-526, 2002.

90. Walter M, Davies JP and Ioannou YA: Telomerase immortalization upregulates Rab9 expression and restores LDL cholesterol egress from Niemann-Pick C1 late endosomes. J Lipid Res 44: 243-253, 2003

91. Jiang LW, Maher VM, McCormick JJ and Schindler M: Alkalinization of the lysosomes is correlated with Ras transformation of murine and human fibroblasts. J Biol Chem 265: 4775-4777, 1990.

92. Martinez-Botas J, Ferruelo AJ, Suarez Y, Fernandez C, Gomez-Coronado D and Lasuncion MA: Dose-dependent effects of lovastatin on cell cycle progression. Distinct requirement of cholesterol and non-sterol mevalonate derivatives. Biochim Biophys Acta 1532: 185-194, 2001.

93. Condon J, Yin S, Mayhew B, Word RA, Wright WE, Shay JW and Rainey WE: Telomerase immortalization of human myometrial cells. Biol Biol Reprod Reprod 2002: 506-514, 2002

94. McKee JA, Banik SS, Boyer MJ, Hamad NM, Lawson JH, Niklason LE and Counter CM: Human arteries engineered in vitro. EMBO Rep 4: 633-638, 2003.

95. Klinger RY, Blum JL, Hearn B, Lebow B and Niklason LE Relevance and safety of telomerase for human tissue engineering. Proc Natl Nat Acad Sci USA 2006: 2500-2505, 2006.

96. Maximow A: Der Lymphozyt als gemeinsame Stammzelle der verschiedenen Blutelemente in der embryonalen Entwicklung und im postfetalen Leben der Saugetiere. (Demonstrationsvortrag, gehalten in der ausserordentlichen Sitzung der Berliner, Hamatologischen Gesellschaft am 1. Jun 1909. Folia Haematol 8: 125-134, 1909 (In German).

97. Simon NM, Smoller JW, McNamara KL, Maser RS, Zalta AK, Pollack MH, Nierenberg AA, Fava M and Wong KK: Telomere shortening and mood disorders: Preliminary support for a chronic stress model of accelerated aging. Biol Psychiatr 60 432-435, 2006

98. Ramirez R, Carracedo J, Soriano S, Jimenez R, Martin-Malo A Rodriguez M, Blasco M and Aljama P: Stress induced-induced premature senescence in mononuclear cells from patients on long term-term hemodialysis. Am J Kidney Dis 45: 353-359, 2005 .

99. Lung FW, Chen NC and Shu BC: Genetic pathway of major depressive disorder in shortening telomeric length. Psychiatr Genet 17: 195-199, 2007

100. Epel ES, Lin J, Wilhelm FH, Wolkowitz OM, Cawthon R, Adler NE, Dolbier C, Mendes WB and Blackburn EH: Cell aging in relation to stress arousal and cardiovascular disease risk factors. Psychoneuroendocrinology 31: 277-287, 2006.

101. Epel ES, Lin J, Dhabhar FS, Wolkowitz OM, Puterman E, Karan L and Blackburn EH: Dynamics of telomerase activity in response to acute psychological stress. Brain Behav Immun 24: $531-539,2010$ 
102.Zalli A, Carvalho LA, Lin J, Hamer M, Erusalimsky JD, Blackburn EH and Steptoe A: Shorter telomeres with high telomerase activity are associated with raised allostatic load and impoverished psychosocial resources. Proc Natl Acad Sci USA 111: 4519-4524, 2014.

103. Aschbacher K, O'Donovan A, Wolkowitz A, Dhabhar OM, Su FS and Epel E: Good stress, bad stress and oxidative stress: Insights Insights from anticipatory cortisol reactivity. Psychoneuroendocrinology 38: 1698-1708, 2013.

104. Spivak IM, Mikhelson VM and Spivak DL: Telomere length, telomerase activity, stress, and aging. Adv Gerontol 6: 29-35, 2016.

105. Lansdorp PM: Stress, social rank and leukocyte telomere length. Aging Cell 5: 583-584, 2006.

106. Adams J, Martin Ruiz-Ruiz C, Pearce MS, White MS, Parker L and von Zglinicki T: No association between socio economic-economic status and white blood cell telomere length. Aging Cell 6: 125-128, 2007.

107. Epel ES: Psychological and metabolic stress: A recipe for accelerated cellular aging? Hormones 8: 7-22, 2009.

108. O'Donovan A, Lin J, Tillie J, Dhabhar FS, Wolkowitz OM, Blackburn EH and Epel ES: Pessimism correlates with leukocyte telomere shortness and elevated interleukin-6 in post-menopausal women,. Brain Behav Immun 23: 446-449, 2009.

109. Lin J, Epel E and Blackburn E: Telomeres and lifestyle factors: Roles in cellular aging. Mutat Res 730: 85-89, 2012.

110. Farzaneh-Far R, Lin J, Epel ES, Harris WS, Blackburn EH and Whooley MA: Association of marine omega-3 fatty acid levels with telomeric aging in patients with coronary heart disease. JAMA 303: 250-257, 2010.

111. Tsuboi H, Shimoi K, Kinae N, Oguni I, Hori R and Kobayashi F: Depressive symptoms are independently correlated with lipid peroxidation in a female population: Comparison Comparison with vitamins and carotenoids. J Psychosom Res 56: 53-58, 2004

112. Forlenza MJ and Miller GE: Increased serum levels of 8-hydroxy-2'-deoxyguanosine in clinical depression. Psychosom Med 68: 1-7, 2006.

113. Von Zglinicki T: Oxidative stress shortens telomeres. Trends Biochem Sci 27: 339-344, 2002

114. Haendeler J, Hoffmann J, Brandes RP, Zeiher AM and Dimmeler S: Hydrogen peroxide triggers nuclear export of telomerase reverse transcriptase via Src kinase family-dependent phosphorylation of tyrosine 707. Mol Cell Biol 23: 4598-4610, 2003.

115. Romieu I, Garcia-Esteban R, Sunyer J, Rios C, AlcarazZubeldia M, Velasco SR and Holguin F: The effect of supplementation with omega-3 polyunsaturated fatty acids on markers of oxidative stress in elderly exposed to $\mathrm{PM}(2.5)$. Environ Environ Health Perspect 116: 1237-1242, 2008.

116. Graham JE, Christian LM and Kiecolt-Glaser JK: Stress, age, and immune function: Toward a lifespan approach. J Behav Med 29: 389-400, 2006.

117. Kiecolt-Glaser JK, Loving TJ, Stowell JR, Malarkey WB, Lemeshow S, Dickinson SL and Glaser R: Hostile marita interactions, proinflammatory cytokine production, and wound healing. Arch Gen Psychiatry 62: 1377-1384, 2005.

118. Liu JP, Chen SM, Cong YS, Nicholls C, Zhou SF, Tao ZZ and $\mathrm{Li} \mathrm{H}$ : Regulation of telomerase activity by apparently opposing elements. Ageing Res Rev 9: 45-256, 2010.

119. Tu W, Zhang DK, Cheung PT, Tsao SW and Lau YL: Effect of insulin-like growth factor 1 on PHA-stimulated cord blood mononuclear cell telomerase activity. Br J Haematol 104: 785-794, 1999.

120. Haik S, Gauthier LR, Granotier C, Peyrin JM, Lages CS Dormont D and Boussin FD: Fibroblast growth factor 2 up regulates telomerase activity in neural precursor cells. Oncogene 19: 2957-2966, 2000.

121. Kurz DJ, Hong Y, Trivier E, Huang HL, Decary S, Zang GH, Luscher TF and Erusalimsky JD: Fibroblast growth factor-2, but not vascular endothelial growth factor, upregulates telomerase activity in human endothelial cells. Arterioscler Thromb Vasc Biol 23: 748-754, 2003

122. Carmeliet P and Jain RK: Angiogenesis in cancer and other diseases. Nature 407: 249-257, 2000.

123. Trivier E, Kurz DJ, Hong Y, Huang HL and Erusalimsky JD: Differential regulation of telomerase in endothelial cells by fibroblast growth factor-2 and vascular endothelial growth factor-a: Association with replicative life span. Ann NY Acad Sci USA 1019: 111-115, 2004.
124. Bermudez Y, Yang H, Saunders BO, Cheng JQ, Nicosia SV and Kruk PA: VEGF- and LPA-induced telomerase in human ovarian cancer cells is Sp1-dependent. Gynecol Oncol 106: 526-537, 2007.

125. Nakagawa K, Eitsuka T, Inokuchi $\mathrm{H}$ and Miyazawa T: DNA chip analysis of comprehensive food function: Inhibition of angiogenesis and telomerase activity with unsaturated vitamin E Tocotrienol. Biofactors 21: 5-10, 2004.

126. Bermudez Y, Ahmadi S, Lowell NE and Kruk PA: Vitamin E suppresses telomerase activity in ovarian cancer cells. Cancer Detect Prev 31: 119-128, 2007.

127. Jacobs EG, Kroenke C, Lin J, Epel ES, Kenna HA, Blackburn EH and Rasgon NL: Accelerated cell aging in female APOE- $\varepsilon 4$ carriers: Implications Implications for hormone therapy use. PLoS One 8: e54713, 2013.

128. Damjanovic AK, Yang Y, Glaser R, Kiecolt-Glaser JK, Nguyen H, Laskowski B, Zou Y, Beversdorf DQ and Weng NP: Accelerated telomere erosion is associated with a declining immune function of caregivers of Alzheimer's' disease patients. J Immunol 179: 4249-4254, 2007.

129. Effros RB: Ageing and the immune system. Novartis Found Symp 235: 130-149, 2001.

130. Effros RB: Telomerase induction in T cells: A cure for aging and disease? Exp Gerontol 42: 416-420, 2007.

131. Choi J, Fauce SR and Effros RB: Reduced telomerase activity in human T-lymphocytes lymphocytes exposed to cortisol. Brain Behav Immun 22: 600-605, 2008.

132. Ornish D, Lin J, Daubenmier J, Weidner G, Epel E, Kemp C, Magbanua MJ, Marlin R, Yglecias L, Carroll PR and Blackburn EH: Increased telomerase activity and comprehensive lifestyle changes: A pilot study. Lancet Oncol 9: 1048-1057, 2008.

133. Puterman E, Lin J, Blackburn E, O'Donovan A, Adler N and Epel E: The power of exercise: Buffering the effect of chronic stress on telomere length. PLoS One 5: e10837, 2010.

134. Kiefer A, Lin J, Blackburn E and Epel E: Dietary restraint and telomere length in pre- and postmenopausal women. Psychosom Med 70: 845-849, 2008.

135. Puterman E, Epel ES, Lin J, Blackburn EH, Gross JJ, Whooley MA and Cohen BE: Multisystem resiliency moderates the major depression-telomere length association: Findings findings from the heart and soul study. Brain Behav Immun 3: 65-73, 2013.

136. Wolkowitz OM, Mellon SH, Epel ES, Lin J, Dhabhar FS, Su Y, Reus VI, Rosser R, Burke HM, Kupferman E, et al: Leukocyte telomere length in major depression: Correlations with chronicity, inflammation and oxidative stress-preliminary findings. PLoS One 6: 17837, 2011.

137. De Punder K, Heim C, Przesdzing I, Wadhwa PD and Entringer S: Characterization in humans of in vitro leucocyte maximal telomerase activity capacity and association with stress. Philos Trans R Soc B Biol Sci 373: 20160441, 2018.

138. Bauer ME, Vedhara K, Perks P, Wilcock GK, Lightman SL and Shanks N: Chronic stress in caregivers of dementia patients is associated with reduced lymphocyte sensitivity to glucocorticoids. J Neuroimmunol 103: 84-92, 2000.

139. Buchkovich KJ and Greider CW: Telomerase regulation during entry into the cell cycle in normal human T cells. Mol Biol Cell 7: 1443-1454, 1996.

140. Kawauchi K, Ihjima K and Yamada O: IL-2 increases human telomerase reverse transcriptase activity transcriptionally and posttranslationally through phosphatidylinositol 3'-kinase/Akt, heat shock protein 90, and mammalian target of rapamycin in transformed NK cells. J Immunol 174: 5261-5269, 2005.

141. Valenzuela HF and Effros RB: Divergent telomerase and CD28 expression patterns in human CD4 and CD8 T cells following repeated encounters with the same antigenic stimulus. Clin Immunol 105: 117-125, 2002.

142. Jacobs TL, Epel ES, Lin J, Blackburn EH, Wolkowitz OM, Bridwell DA, Zanesco AP, Aichele SR, Sahdra BK, MacLean KA, et al: Intensive meditation training, immune cell telomerase activity, and psychological mediators. Psychoneuroendocrinology 36: 664-681, 2011.

143. Vasilopoulos E, Fragkiadaki P, Kalliora C, Fragou D, Docea AO, Vakonaki E, Tsoukalas D, Calina D, Buga AM, Georgiadis G, et al: The association of female and male infertility with telomere length (Review). Int J Mol Med 44: 375-389, 2019. 
144. Fragkiadaki P, Tsoukalas D, Fragkiadoulaki I, Psycharakis C Nikitovic D, Spandidos DA and Tsatsakis A: Telomerase activity in pregnancy complications (Review). Mol Med Rep 14: $16-21,2016$

145. Cohen S, Janicki-Deverts D and Miller GE: Psychological stress and disease. JAMA 298: 1685-1687, 2007.

146. Monaghan P: Organismal stress, telomeres and life histories. J Exp Biol 217: 57-66, 2014.

147. Kiecolt-Glaser JK and Glaser R: Psychological stress, telomeres, and telomerase. Brain Behav Immun 24: 529-530, 2010.

148. Lazarides C, Epel E, Lin J, Blackburn E, Voelkle M, Buss C, Simhan H, Wadhwa P and Entringer S: Maternal pro-inflammatory state during pregnancy and newborn leukocyte telomere length: A prospective investigation. Brain Behav Immun 80 419-426, 2019.

149. Shivappa N, Steck SE, Hurley TG, Hussey JR and Hébert JR Designing and developing a literature-derived, population based dietary inflammatory index. Public Health Nutr 17: 1689-1696, 2014

150. Shivappa N, Steck SE, Hurley TG, Hussey JR, Ma Y, Ockene IS, Tabung F and Hébert JR: A population-based dietary inflammatory index predicts levels of C-reactive protein in the Seasonal Variation of Blood Cholesterol Study (SEASONS). Public Health Nutr 17: 1825-1833, 2014.

151. Shivappa N, Hébert JR, Rietzschel ER, De Buyzere ML, Langlois M, Debruyne E, Marcos A and Huybrechts I: Associations between dietary inflammatory index and inflammatory markers in the Asklepios Study. Br J Nutr 113: 665-671, 2015.

152. Shivappa N, Wirth MD, Hurley TG and Hébert JR: Association between the dietary inflammatory index (DII) and telomere length and C-reactive protein from the National Health and Nutrition Examination Survey-1999-2002. Mol Nutr Food Res 61: 1600630, 2017.

153. Simopoulos AP: The importance of the omega-6/omega- 3 fatty acid ratio in cardiovascular disease and other chronic diseases. Exp Biol Med (Maywood) 233: 674-688, 2008.

154. Papamichael MM, Shrestha SK, Itsiopoulos C and Erbas B: The role of fish intake on asthma in children: A meta-analysis of observational studies. Pediatr Allergy Immunol 29: 350-360, 2018.

155. Kiecolt-Glaser JK, Epel ES, Belury MA, Andridge R, Lin J, Glaser R, Malarkey WB, Hwang BS and Blackburn E: Omega-3 fatty acids, oxidative stress, and leukocyte telomere length: A randomized controlled trial. Brain Behav Immun 28: 16-24, 2013.

156. Tsoukalas D, Fragkiadaki P, Docea AO, Alegakis AK, Sarandi E, Vakonaki E, Salata E, Kouvid E, Nikitovic D, Kovatsi L, et al Association of nutraceutical supplements with longer telomere length. Int J Mol Med 44: 218-226, 2019.

157. Tsatsakis A, Tsoukalas D, Fragkiadaki P, Vakonaki E, Tzatzarakis M, Sarandi E, Nikitovic D, Tsilimidos G and Alegakis AK: Developing BIOTEL: A semi-automated spreadsheet for estimating telomere length and biological age. Front Genet 10: 84, 2019.

158. Tsoukalas D, Fragkiadaki P, Docea AO, Alegakis AK, Sarandi E Thanasoula M, Spandidos DA, Tsatsakis A, Razgonova MP and Calina D: Discovery of potent telomerase activators: Unfolding new therapeutic and anti-aging perspectives. Mol Med Rep 20 3701-3708, 2019.

159. Fragkiadaki P, Nikitovic D, Kalliantasi K, Sarandi E, Thanasoula M, Stivaktakis DP, Nepka C, Spandidos AD, Tosounidis T and Tsatsakis A: Telomere length and telomerase activity in osteoporosis and osteoarthritis. Exp Ther Med 19: $1626-1632,2020$

160. Olovnikov AM: How could the program of aging be arranged? Russ J Gen Chem 80: 1482-1489, 2010.

161. Olovnikov AM: Chronographic theory of development, aging, and origin of cancer: Role of chronomeres and printomeres. Curr Aging Sci 8: 76-88, 2015.

162. Anisimov VN: Molecular and physiological mechanisms of aging. Vol 2. 2nd edition. St. Petersburg, Nauka, 2003 (In Russian)

163. Mitteldorf JJ: How does the body know how old it is? Introducing the epigenetic clock hypothesis. Biochemistry (Mosc) 78 1048-1053, 2013

164. Severin FF, Feniouk BA and Skulachev VP: Advanced glycation of cellular proteins as a possible basic component of the "master biological clock'. Biochemistry (Mosc) 78: 1043-1047, 2013.

165. Pisaruk AV: Ontogenetic clock: Molecular-genetic mechanism. Adv Gerontol 23: 527-535, 2010 (In Russian).
166. Lund J, Tedesco P, Duke K, Wang J, Kim SK and Johnson TE: Transcriptional profile of aging in C. elegans. Curr Biol 12: 1566-1573, 2002

167. Halaschek-Wiener J, Khattra JS, McKay S, Pouzyrev A, Stott JM, Yang GS, Holt RA, Jones SJ, Marra MA, Brooks-Wilson AR and Riddle DL: Analysis of long-lived C. elegans daf-2 mutants using serial analysis of gene expression. Genome Res 15: 603-615, 2005.

168. Golden TR and Melov S: Gene expression changes associated with aging in C. elegans. In: WormBook: The Online Review of C. elegans Biology. WormBook, Pasadena, CA, 2005-2018.

169. Herndon LA, Schmeissner PJ, Dudaronek JM, Brown PA, Listner KM, Sakano Y, Paupard MC, Hall DH and Driscoll M: Stochastic and genetic factors influence tissue-specific decline in ageing C. elegans. Nature 419: 808-814, 2002.

170. Thaden JJ and Shmookler Reis RJ: Ammonia, respiration, and longevity in nematodes: Insights on metabolic regulation of life span from temporal rescaling. J Am Aging Assoc 23: 75-84, 2000.

171. Olovnikov AM: Hypothesis: Lifespan is regulated by chronomere DNA of the hypothalamus. J Alzheimers Dis 11: 241-252, 2007.

172. Andoniadou CL and Martinez-Barbera JP: Developmental mechanisms directing early anterior forebrain specification in vertebrates. Cell Mol Life Sci 70: 3739-3752, 2013.

173. Bayramov AV, Eroshkin FM, Martynova NY, Ermakova GV, Solovieva EA and Zaraisky AG: Novel functions of Noggin proteins: Inhibition of Activin/Nodal and Wnt signaling. Development 138: 5345-5356, 2011.

174. Lewis DA: Development of the prefrontal cortex during adolescence: Insights into vulnerable neural circuits in schizophrenia. Neuropsychopharmacology 16: 385-398, 1997.

175. Rzeczkowska PA, Hou H, Wilson MD and Palmert MR: Epigenetics: A new player in the regulation of mammalian puberty. Neuroendocrinology 99: 139-155, 2014

176. Lieber $M$ and Blumenthal HT: Lifespan changes in the index of cephalization. Exp Aging Res 10: 127-135, 1984

177. Arendt T: Alzheimer's disease as a loss of differentiation control in a subset of neurons that retain immature features in the adult brain. Neurobiol Aging 21: 783-796, 2000.

178. Park DC, Polk TA, Park R, Minear M, Savage A and Smith MR: Aging reduces neural specialization in ventral visual cortex. Proc Natl Acad Sci USA 101: 13091-13095, 2004.

179. Voss MW, Erickson KI, Chaddock L, Prakash RS, Colcombe SJ, Morris KS, Doerksen S, Hu L, McAuley E and Kramer AF: Dedifferentiation in the visual cortex: An fMRI investigation of individual differences in older adults. Brain Res 1244: 121-131, 2008.

180. Rajah MN and D'Esposito M: Region-specific changes in prefrontal function with age: A review of PET and fMRI studies on working and episodic memory. Brain 128: 1964-1983, 2005.

181. Dreher JC, Meyer-Lindenberg A, Kohn P and Berman KF: Age-related changes in midbrain dopaminergic regulation of the human reward system. Proc Natl Acad Sci USA 105: 15106-15111, 2008

182. Raz N, Lindenberger U, Rodrigue KM, Kennedy KM, Head D, Williamson A, Dahle C, Gerstorf D and Acker JD: Regional brain changes in aging healthy adults: General trends, individual differences and modifiers. Cereb Cortex 15: 1676-1689, 2005.

183. Desgranges B, Kalpouzos G and Eustache F: (Cerebral imaging in healthy aging: Contrast with Alzheimer disease). Rev Neurol (Paris) 164 (Suppl 3): S102-S107, 2008.

184. Andrews-Hanna JR, Snyder AZ, Vincent JL, Lustig C, Head D, Raichle ME and Buckner RL: Disruption of large-scale brain systems in advanced aging. Neuron 56: 924-935, 2007.

185. Fotenos AF, Snyder AZ, Girton LE, Morris JC and Buckner RL: Normative estimates of cross-sectional and longitudinal brain volume decline in aging and AD. Neurology 64: 1032-1039, 2005.

186. Fotenos AF, Mintun MA, Snyder AZ, Morris JC and Buckner RL: Brain volume decline in aging: Evidence for a relation between socioeconomic status, preclinical Alzheimer disease, and reserve. Arch Neurol 65: 113-120, 2008.

187. Yamanishi Y, Hiyama K, Maeda H, Ishioka S, Murakami T, Hiyama E, Kurose Y, Shay JW and Yamakido M: Telomerase activity in rheumatoid synovium correlates with the mononuclear cell infiltration level and disease aggressiveness of rheumatoid arthritis. J Rheumatol 25: 214-220, 1998. 
188. Tarhan F, Vural F, Rosova B, Aksu K, Cogulu O, Keser G, Gunduz C, Tombuloglu M, Oder C, Karaca E and DoganavsargilE: Telomerase activity in connective tissue diseases: Elevated in rheumatoid arthritis, but markedly decreased in systemic sclerosis. Rheumatol Int 28: 579-583, 2008.

189. Kurosaka D, Yasuda J, Yoshida K, Yokoyama T, Ozawa Y, Obayashi Y, Kingetsu I, Saito S and Yamada A: Telomerase activity and telomere length of peripheral blood mononuclear cells in SLE patients. Lupus 12: 591-599, 2003.

190. Hug A, Korporal M, Schröder I, Haas J, Glatz K, Storch-Hagenlocher B and Wildemann B: Thymic export function and $\mathrm{T}$ cell homeostasis in patients with relapsing remitting multiple sclerosis. J Immunol 171: 432-437, 2003.

191. Jang HS, Oh CK, Jo JH, Kim YS and Kwon KS: Detection of telomerase activity in psoriasis lesional skin and correlation with $\mathrm{Ki}-67$ expression and suppression by retinoic acid. J Korean Med Sci 16: 623-629, 2001.

192. Ogoshi M, Le T, Shay JW and Taylor RS: In situ hybridization analysis of the expression of human telomerase RNA in normal and pathologic conditions of the skin. J Invest Dermatol 110 818-823, 1998.

193. Taylor RS, Ramirez RD, Ogoshi M, Chaffins M, Piatyszek MA and Shay JW: Detection of telomerase activity in malignant and nonmalignant skin conditions. J Invest Dermatol 106: 759-765, 1996.

194. Brümmendorf TH, Maciejewski JP, Mak J, Young NS and Lansdorp PM: Telomere length in leukocyte subpopulations of patients with aplastic anemia. Blood 97: 895-900, 2001.
195. Fogarty PF, Yamaguchi H, Wiestner A, Baerlocher GM, Sloand E, Zeng WS, Read EJ, Lansdorp PM and Young NS: Late presentation of dyskeratosis congenita as apparently acquired aplastic anaemia due to mutations in telomerase RNA. Lancet 362: 1628-1630, 2003.

196. Ly H: Genetic and environmental factors influencing human diseases with telomere dysfunction. Int J Clin Exp Med 2: 114-130, 2009.

197. Young NS: Pathophysiologic mechanisms in acquired aplastic anemia. Hematology Am Soc Hematol Educ Program 2006 72-77, 2006.

198. Yamaguchi H, Calado RT, Ly H, Kajigaya S, Baerlocher GM, Chanock SJ, Lansdorp PM and Young NS: Mutations in TERT, the gene for telomerase reverse transcriptase, in aplastic anemia. N Engl J Med 352: 1413-1424, 2005.

199. Marrone A, Stevens D, Vulliamy T, Dokal I and Mason PJ: Heterozygous telomerase RNA mutations found in dyskeratosis congenita and aplastic anemia reduce telomerase activity via haploinsufficiency. Blood 104: 3936-3942, 2004.

This work is licensed under a Creative Commons Attribution-NonCommercial-NoDerivatives 4.0 International (CC BY-NC-ND 4.0) License. 